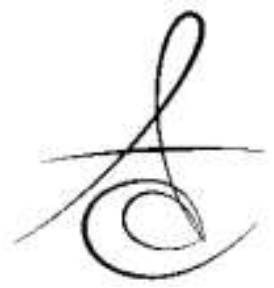

\title{
PRENATAL DÖNEMDEN İTİBAREN SİSTEMİK FLUOR VERİLEN SIÇANLARIN BÖBREK DOKULARINDA GÖRÜLEN APOPTOZISİN İNCELENMESİ ${ }^{\neq}$
}

\author{
INVESTIGATION OF APOPTOSIS IN RENAL TISSUES OF RATS EXPOSED FROM \\ PRENATAL PERIOD TO SYSTEMIC FLUORIDE ${ }^{\neq}$
}

\author{
Dr. Öğr. Üyesi Serhat KARACA* \\ Doç Dr. İlker TÍNAY***
}

Prof. Dr. Ali MENTEŞ

\author{
Dr. Öğr. Üyesi Şirin GÜNER ONUR* \\ Prof. Dr. Süheyla UYAR BOZKURT ${ }^{* * * *}$
}

Makale Kodu/Article code: 4332

Makale Gönderilme tarihi: 02.03 .2020

Kabul Tarihi: 21.08.2020

DOI: $10.17567 /$ ataunidfd. 783461
Serhat Karaca: ORCID ID: 0000-0003-1588-1480

Şirin Güner Onur: ORCID ID: 0000-0002-6890-3500

İlker Tinay: ORCID ID: 0000-0001-6768-9373

Süheyla Uyar Bozkurt: ORCID ID: 0000-0002-5947-947x

Ali Menteș: ORCID ID: 0000-0002-2778-6803

ÖZ

Amaç: Bu çalışmanın amacı prenatal dönemden itibaren değişik konsantrasyonlarda sistemik fluora (F) maruz kalan sıçanlarda; F'nin, böbrek dokuları üzerindeki toksik etkilerinin incelenmesi ve meydana gelen histopatolojik değişikliklerin araștırılmasıdır. Gereç ve yöntem: Bu çalışmada, daha önceden prenatal dönemden itibaren içme suyu ile 0,30 ve 100 ppm $F$ dozları verilen ve 1., 3. ile 5. aylarda sakrifiye edilen sıçanlara ait böbrek dokuları kullanılmıştır. Histolojik değerlendirme için hematoksilen ve eozin (H\&E), immünohistokimyasal inceleme için ise TUNEL yöntemi ile boyama yapılarak, tubulus ve glomerulus bölgelerinde meydana gelen apoptozis değerlendirilmiştir.

Bulgular: 100 ppm F gruplarında tespit edilen apoptotik hücre sayısı, kontrol grubu ve 30 ppm F grubununa kıyasla anlamlı derecede yüksek bulunmuştur. Ayrıca hem tubulus hem de glomerulus bölgelerinde, tüm sıçanlarda böbrek dokularının 5 . ay apoptozis değerlerinin, 1 . ve 3. ay değerlerinden anlamlı şekilde olduğu tespit edilmiştir. Böbrek dokularında yapılan histolojik incelemelerde ise içme suyundaki $\mathrm{F}$ miktarının artması ile tübüler dilatasyon, glomeruluslarda atrofi ve nekroz alanları, vasküler konjesyon ve hemorajik kanama odakları gözlemlenmiştir.

Sonuç: Yüksek F konsantrasyonunda sıçan böbrek dokularında apoptoziste artış ve belirgin bir yıkım gözlenmiştir.

Anahtar sözcükler: fluor, böbrek, TUNEL, apoptozis

\section{ABSTRACT}

Aim: The aim of this study was to evaluate fluoride $(F)$ induced toxic effects and histopathological changes on renal tissues of rats exposed to different concentrations of fluoride pre and postnatally.

Material and Methods: Kidneys of the rats that had received 0,30 and $100 \mathrm{ppm} F$ in drinking water starting from the prenatal period and sacrificed at first, third and fifth months were used in this study. Renal tissues were sectioned and stained with hematoxylin and eosin (H\&E) for histological analysis and with TUNEL technique for immunohistochemical evaluations of apoptosis in glomerular and tubular sections.

Results: In the $100 \mathrm{ppm} F$ group, the number of glomerular and tubular apoptotic cells were significantly higher than control and $30 \mathrm{ppm} F$ groups. In all groups, higher apoptosis was detected in the 5th month than the 1st and 3rd months in glomerular and tubular sections and the differences were statistically significant. The transverse section of kidney of the 5th month rat group showed tubular dilatations, glomerular atrophies and necrosis areas, vascular congestions and hemorrhagic regions.

Conclusion: High F doses administered in drinking water caused severe apoptosis and a marked destruction in rat kidney tissues.

Key Words: fluoride, kidney, TUNEL, apoptosis

*Erzincan Binali Yıldırım Üniversitesi Diş Hekimliği Fakültesi Pedodonti Anabilim Dalı

**Trakya Üniversitesi Diş Hekimliği Fakültesi Çocuk Diş Hekimliği Anabilim Dalı

***Marmara Üniversitesi Tıp Fakültesi Patoloji Anabilim Dalı

$* * * *$ Marmara Üniversitesi Tıp Fakültesi Üroloji Anabilim Dalı

*****Marmara Üniversitesi Diș Hekimliği Fakültesi Pedodonti Anabilim Dalı

FBu tez, Marmara Üniversitesi Bilimsel Araştırma Projeleri Komisyonu Başkanlığı tarafından SAG-C-DRP-141112-0332 numaralı proje ile desteklenmistir.

Kaynakça Bilgisi: Karaca S, Güner Onur Ş, Tinay İ, Uyar Bozkurt S, Menteş A. Prenatal dönemden itibaren sistemik fluor verilen sıçanların böbrek dokularında görülen apoptozisin incelenmesi. Atatürk Üniv Diş Hek Fak Derg 2020; 30: 571-8.

Citation Information: Karaca S, Guner Onur S, Tinay I, Uyar Bozkurt S, Mentes A. Investigation of apoptosis in renal tissues o rats exposed from prenatal period to systemic fluoride. J Dent Fac Atatürk Uni 2020; 30: 571-8. 


\section{GİRİŞ}

Fluor (F) halojenler grubuna ait elektronegativitesi ve reaktivitesi yüksek bir elementtir. ${ }^{1-3}$ Yeryüzü kabuğunun yaklaşık $0,3 \mathrm{gr} / \mathrm{kg}^{\prime}$ nin oluşturan $F$, doğada genellikle hava, toprak, su, bitki ve hayvansal dokularda farklı bileşik ve miktarlarda bulunmaktadır. ${ }^{3,4}$ İçme suyu canlıar için önemli bir $\mathrm{F}$ alım kaynağıdır., 3 Dünya Sağlık Örgütü'ne göre içme suyunda bulunması gereken $\mathrm{F}$ miktarı $0.5-1.5 \mathrm{mg} / \mathrm{l}$ değerleri arasında olmalıdır. İçme sularındaki $\mathrm{F}$ miktarını 1,5 $\mathrm{mg} / \mathrm{l}$ 'nin üzerine çıktığı durumlarda ise fluorozis meydana gelebilmektedir. ${ }^{6}$ İnsan vücudunda bulunan F'nin \%99'u özellikle kemik, mine ve dentin olmak üzere mineralize dokularda birikmektedir. ${ }^{7}$

Dental fluorozis, optimal düzeyin üzerindeki $\mathrm{F}^{\prime}$ nin dişlerin gelişim aşamasında, sistemik olarak alımı ile meydana gelen, dişlerde simetrik dağılım gösteren normal mine yapısına göre poroziteler ile karakterize bir mine bozukluğudur. ${ }^{8-11} \mathrm{~F}$, dişlerde oluşturduğu estetik bozuklukların yanı sıra kemikte de birtakım bozukluklar meydana getirebilmektedir. F'nin uzun süre oral yol ile yüksek dozda alınması, iskeletsel dokularda $\mathrm{F}$ tutulumuna ve patolojik kemik deformasyonlarına yol açmaktadır. ${ }^{2,12}$ Doğal içme suyu kaynaklarında $\mathrm{F}$ konsantrasyonu günlük optimal $\mathrm{F}$ dozundan daha yüksek olan coğrafi bölgelerde yaşayan bireylerde görülen endemik fluorozis günümüzde önemli bir halk sağlığı sorunudur.

Oral yolla alınan F'nin birincil atılım yeri olduğundan dolayı böbrekler diğer organlardan daha fazla F'ye maruz kalmaktadırlar. Bu durum uzun süre F'ye maruziyetin böbrekler üzerine toksik etkisi olabileceğini akla getirmiştir. Yapılan çalışmalarda, aşıı $F$ alımının renal yetmezlikle ilişkili olabileceği bildirilmiştir. ${ }^{13}$ Normal şartlar altında 18-75 yaş arası sağlıkı bireylerin günlük atılan idrarında alınan F'nin yaklaşık \%60'ı bulunur. Çocuklarda bu oran $\% 45^{\prime}$ dir. Bunun sonucu olarak plazma ile idrar bir fizyolojik denge oluşturur. ${ }^{14}$ $B$ Bu denge daha önce alınmış $F$ miktarı, daha önce birikmiş $\mathrm{F}$ miktarı, kemikten çözünen $\mathrm{F}$ ve böbreklerin $F$ atma etkinliğine bağlıdır. Dolayısıyla böbreklerdeki patoloji direk olarak alınan F miktarı ile ilişkilidir. Her ne kadar böbrek hastalığı olan çocuklarda yapılmış çalışmalarda dental fluorozis görülme sıklığı sağlıklı çocuklara göre anlamlı bir fark göstermemiş olsa da özellikle şiddetli dental fluorozis eğiliminin bu çocuklarda arttığı not edilmiştir. Endemik fluorozis bölgelerinde yapılan çalışmalarda, böbrek fonksiyonlarıyla $F$ toksisitesi arasında ilişki kurulmuştur. ${ }^{15-18}$
Organizma sürekli bir denge halindedir. Yeni hücreler sentez edilirken var olan hücrelerin bir kısmı hücre ölümü ile ortadan kalkmakta ve böylece denge korunmaktadır. Hücre ölümünün iki tipi vardır, bunlar apoptozis ve nekrozdur. ${ }^{19}$ Her ikisi de düzenli olarak birbirini izleyen biyokimyasal ve morfolojik olaylar sonucu meydana gelir. Hücre proliferasyonu nasıl ki mitoz ile belirlenmekte ise belirli bir dokuda olması gereken hücre sayısı da apoptozis ile belirlenir. Apoptozis ve mitozis dokuda sürekli bir denge halindedir. Çevreden gelen toksik olsun veya olmasın farklı etkenler de bunu tetiklemektedir. ${ }^{20,21}$

Temel tıp bilimlerinde, başta sıçan ve fare olmak üzere deney hayvanları insanlara benzer histolojik ve fonksiyonel hücrelere sahip olduklarından doku cevaplarını araştıran çalışmalarda tercih edilmektedirler. Günümüzde, toksisite araştırmalarında dokudaki olası toksik etkilerin tespit edilmesinde sıklıkla deney hayvanları kullanılmaktadır. Bu çalışmanın amacı prenatal dönemden itibaren içme suyuna 0,30 veya 100 ppm F katılarak doğumdan itibaren 1,3 ve 5 ay süresince takip edilen sıçanlara ait böbrek dokularının tubulus ve glomerulus bölgelerinde oluşan apoptotik hücre değişikliklerini histolojik ve immünohistokimyasal yöntemler kullanılarak değerlendirilmesidir.

\section{GEREÇ VE YÖNTEM}

Araştırmamız, Marmara Üniversitesi Deney Hayvanı Araştırma Etik Kurulu Başkanlığından 66.2012.mar.12072012 sayısı ile onay almış olup, 23.09.2010 tarih ve "66.2010.mar" sayısı Marmara Üniversitesi Deney Hayvanı Araşıtıma Etik Kurulu Başkanlığı́ndan onay alan ve Marmara Üniversitesi Diş Hekimliği Fakültesi Pedodonti Ana Bilim Dalı'nda yapılan "Doğum öncesi ve sonrası kronik olarak değişik konsantrasyonlarda sistemik $F$ verilen yavru ratların diş, kemik ve beyin dokularının makroskopik ve mikroskopik incelenmesi" isimli çalışma sırasında kullanılan sıçanlardan alınan böbrek dokuları ile yapıımışıı. ${ }^{22}$

$\mathrm{Bu}$ çalışmada kullanılan deney hayvanlarının gruplarının hazırlanması ve uygulanması daha önceki çalışmamızda anlatılmıştır. ${ }^{22}$ Kısaca özetlersek, Marmara Üniversitesi Deney Hayvanları Uygulama ve Araştırma Merkezi'nde üretilen Wistar albino dişi sıçanlara 0 (kontrol), 30 ve $100 \mathrm{ppm} F$ içeren içme suları ad libitum verilmiştir. Doğumu takiben 63 erkek yavru sıçan, her grupta 21 sıçan olacak şekilde üç gruba ayrılmış, 1 ay, 3 ay ve 5 ay süresince takip edilerek sakrifiye edilmiş ve böbrek dokuları çıkarılarak $\% 10^{\prime}$ luk nötral tamponlu formaldehit solüsyonunda 
oda sıcaklığında saklanmıştır. Fikse edilen böbrek dokula- rından renal parankim ve medüller bölgeyi içeren kat dilimler alınarak otomatik doku takip cihazında doku tespiti yapılmıştır. Dokulardan parafin bloklar hazırlan- mış ve H\&E boyama ve immünohistokimyasal değer- lendirme için pozitif şarjlı lamlar üzerine $3 \mu \mathrm{m}$ kalınlığında kesitler alınmıştır.

\section{Deney hayvanlarından böbrek doku örneklerinin histolojik incelenmesi}

H\&E boyama işlemi için lamlara alınan $3 \mu \mathrm{m}$ kalınlığındaki kesitler $65^{\circ} \mathrm{C}$ etüvde 1 saat bekletilmiştir. Ardından ksilen içine alınarak 3x5 dakika bekletilmiştir. Daha sonra 3 ayrı \%96'lik alkol serisi içine alınan kesitler birer dakika bekletilmiştir. Musluk suyu ile iyice yıkanan kesitler 2 dakika H\&E boyası uygulandıktan sonra 1 dakika akar çesme suyunda yıkanarak morartılmıştır. Kesitler alkol içine alınmıştır. Daha sonra kesitler 2 dakika alkolik eosin ile boyanmış ve 3 defa \%96'lik alkol serisi ve 2 defa aseton serisinden geçirilmiştir. Kuruması için etüve alınan kesitler daha sonra ksilen içine alınarak entellan ve lamel ile kapatılmıştır.

\section{Böbrek dokularının immünohistokimyasal yöntem ile incelenmesi}

Böbrek dokularında immunohistokimyasal inceleme için pozitif şarjlı lamlara alınan kesitlere TUNEL (terminal deoxynucleotidyl transferase mediated dUTP nick end labeling) yöntemi uygulanarak apoptozis değerlendirilmiştir. Araştırmamızda Roche Diagnostics $\mathrm{GmbH}$; Mannheim, Germany firmasının 11684817910 katalog numaralı DNA fragmantasyonu tespit kitleri kullanılmıştır.

Kısaca, mum giderme ve rehidrasyondan sonra, bölümler proteinaz $\mathrm{K}$ ile 30 dakika inkübe edilmiş, PBS ile yıkanmış, sonra $4^{\circ} \mathrm{C}$ de 2 dakika inkübe edilmiştir. Kesitler, TUNEL karışım reaksiyon çözeltisi ile $37^{\circ} \mathrm{C}$ de 60 dakika süreyle inkübe edilmiş, ardından alkalin fosfataz dönüşüm çözeltisi ile $37{ }^{\circ} \mathrm{C}$ 'de 30 dakika süreyle inkübe edilmiştir. PBS içinde yıkandıktan sonra, bölümler 20 dakika boyunca $25^{\circ} \mathrm{C}$ 'de NBT / BCIP ile inkübe edilmiş, musluk suyunda yıkanmış ve nükleer hızı kırmızı ile ters boyanmıştır. Apoptotik hücreler kahverengi renk ile boyanmıştır.

\section{Böbrek dokularında apoptotik hücre sayımı ve değerlendirilmesi}

TUNEL boyalı kesitler ışık mikroskobunda (Olympus BX50) incelenmiş ve X400 büyütmede sayılarak skorlanmıştır. Mikroskopta ekli kamera aracılığı ile X200 ve X400 büyütmede fotoğraflanmıştır (Olympus SC 100). Böbrek glomerül ve tubulus alanlarındaki TUNEL ile boyanan hücre nükleusları
X400 büyütme altında, rastgele alanlar sayılarak ayrı ayrı değerlendirilerek ortalamaları alınmıştır.

Her bir böbrek dokusunda optimum boyanma gösteren rastgele 3 adet glomerülde kahverengi apoptotik hücrelerin ilgili glomerüldeki oranı incelenmiştir. Glomerüldeki tüm hücrelerin sayısı ve kahverengi boyanan apoptotik hücreler sayılarak, glomerül başına apoptotik yüzde değerleri elde edilmiştir. Böbrek dokularındaki tubulus bölgelerinin apoptozis değerlendirmesinde her böbrekte optimum boyanma gösteren rastgele 1000 tübül hücresi incelenmiştir ve kahverengi boyanan apoptotik hücrelerin tubulus hücre sayısına oranı yüzde olarak değerlendirilmiştir.

\section{İstatistiksel Analiz}

Çalışmamızda, böbrek dokularının tubulus ve glomerulus bölgelerinden elde edilen apoptozis değerleri ayrı ayrı incelenirken, istatistiksel analizler için 'Graphpad prism 5.1" istatistik analiz programı kullanılmıştır. Böbrek dokularında apoptozis değerleri için tüm gruplar birbirleriyle oneway ANOVA post hoc tukey istatistiksel testi kullanılarak karşılaştırımıştır. Gruplar arasında $\mathrm{p}<0,05$ istatistiksel açıdan anlamlı kabul edilmiştir.

\section{BULGULAR}

1., 3. ve 5. ay (Resim 1a) kontrol grubuna ait böbrek doku örneklerinden alınan kesitlerde glomerulus ve tubulus bölgelerinde normal hücre yapısı gözlenmiştir. 30 ppm F 1. ay grubunda yer alan sıçanlara ait histolojik kesitlerde kontrol grubuna benzer hücre yapıları izlenmiştir ve histolojik hasara rastlanmamıştır. 100 ppm F 1. ay grubunda yer alan sıçanlara ait histolojik kesitlerde glomerulus ve tubulus bölgelerinde çok belirgin olmamakla beraber glomeruluslarda hafif derecede atrofi; tubul yapılarında ise yine hafif derecede dilatasyon mevcuttur.

30 ppm F 3. ay grubunun böbrek dokularının histolojik incelemelerinde hafif düzeyde glomerül içinde kanama ve vasküler konjesyon izlenirken genel glomerül yapısında atrofi ve nekroz alanları gözlemlenmiştir. Tubuluslarda ise tübüler dilatasyon mevcuttur. 100 ppm F 3. ay grubunda böbrek dokularının glomerulus ve tubulus bölgelerinde kontrol ve 30 ppm gruplarına göre daha belirgin histolojik değişiklikler izlenmiştir. Glomerüllerde büzülme ve küçülme şeklinde atrofi, tubulus bölgelerinde dilatasyon izlenmiştir.

5. ay kontrol ve deney grubu sıçanların daha büyük olmasından dolayı glomerül ve tübül yapıları da 
1. ve 3. ay grubu hayvanlara göre daha büyüklerdir. 30 ppm F 5. ay grubu deney hayvanlarının böbrek dokularında, diğer gruplara göre glomerüller ve tubullerde büyüklük açısından bariz bir fark izlenmiştir. Glomerüllerde hafif konjesyon ve atrofi görülmüştür. 100 ppm F 5. ay grubu deney hayvanlarında histolojik açıdan glomerüllerde belirgin düzeyde atrofi ve nekroz alanları görülmüştür. (Resim 1b) Tubuluslarda ise dilatasyon mevcuttur. Bu deney grubu sıçanlarda böbrek dokularında hemorajik kanama odakları ve eritrositler de gözlemlenmiştir.

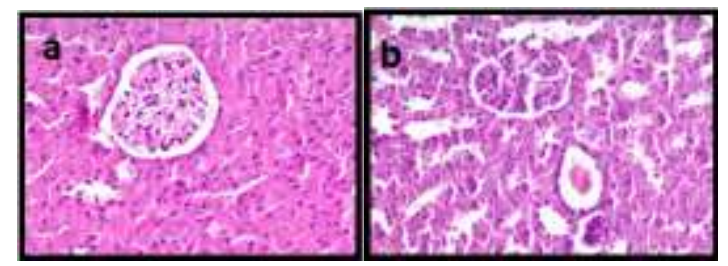

Resim 1. (a) Kontrol 5. ay grubu böbrek dokusu normal glomerüler ve tübüler yapı ve (b) 100 ppm F 5. ay grubu böbrek dokusu glomerulusta atrofi hematoksilen eozin boyama x 400 büyütme

Tubulus bölgelerinde apoptotik hücrelerin analizi ve değerlendirilmesi

Tubulus bölgesinde, Kontrol gruplarında 5. ay değerleri, 1 . ay değerlerine göre $(p=0.0004)$ ve 3 . ay değerlerine göre $(p<0.05)$ anlamlı şekilde yüksektir. Kontrol grubu 1. ay ve 3. ay değerleri arasında anlamlı bir farklılık gözlememiştir ( $p>0.05$ ) Tubulus bölgesinde, 30 ppm F grubu 5. ay değerleri, 1. ay değerlerine göre $(p=0.0006)$ ve 3 . ay değerlerine göre $(p=0.0006)$ anlamlı şekilde yüksektir. 30 ppm $\mathrm{F}$ grubu 1 . ay ve 3 . ay değerleri arasında anlamlı bir farklılık bulunmamaktadır. Tubulus bölgesinde 100 ppm F grubu 5. ay değerleri, 1 . ay değerlerine göre $(p=0.0003)$ ve 3 . ay değerlerine göre $(p=0.0003)$ anlamlı şekilde yüksektir. 100 ppm F grubu 1. ay ve 3. ay değerleri arasında anlamlı bir farklılık bulunmamaktadır. (Tablo 1)

Tablo 1. Böbrek dokusu tubulus bölgeleri apoptotik hücre yüzde değerleri.

\begin{tabular}{|c|c|c|c|c|}
\hline $\begin{array}{l}\text { Takip } \\
\text { Süresi }\end{array}$ & $\begin{array}{l}\text { Kontrol } \\
\text { Ort } \pm \text { SS } \\
\text { (Medyan) }\end{array}$ & $\begin{array}{l}30 \mathrm{ppm} F \\
\text { Ort } \pm \text { SS } \\
\text { (Medyan) }\end{array}$ & $\begin{array}{l}100 \mathrm{ppm} \mathrm{F} \\
\text { Ort } \pm \text { SS } \\
\text { (Medyan) }\end{array}$ & $p$ \\
\hline 1 ay & $\begin{array}{l}45.83 \pm 5.56 \\
(46.36)\end{array}$ & $\begin{array}{l}49.98 \pm 6.28 \\
(50.90)\end{array}$ & $\begin{array}{l}80.22 \pm 3.16 \\
(80.70)\end{array}$ & $<0.0001$ \\
\hline 3 ay & $\begin{array}{l}50.23 \pm 4.04 \\
(51.12)\end{array}$ & $\begin{array}{l}50.66 \pm 4.83 \\
(50.00)\end{array}$ & $\begin{array}{l}84.31 \pm 3.59 \\
(84.35)\end{array}$ & $<0.0001$ \\
\hline 5 ay & $\begin{array}{l}56.99 \pm 3.70 \\
(58.20)\end{array}$ & $\begin{array}{l}60.74 \pm 3.94 \\
(61.13)\end{array}$ & $\begin{array}{l}91.45 \pm 1.77 \\
(91.80)\end{array}$ & $<0.0001$ \\
\hline $\mathrm{p}$ & 0.0004 & 0.0006 & 0.0003 & - \\
\hline
\end{tabular}

Oneway ANOVA * p<0,05
Tubulus bölgesinde, takip sürelerine göre 100 ppm $F$ grubu 1. ay değerleri, kontrol grubu 1. ay değerlerinden $(p<0.0001)$ ve $30 \mathrm{ppm} F$ grupları 1 . ay değerlerine göre $(p<0.0001)$ anlamlı şekilde yüksektir. Kontrol grubu ile 30 ppm F grubu 1. ay değerleri arasında anlamlı bir farklılık bulunmamaktadır. (Şekil 1a)

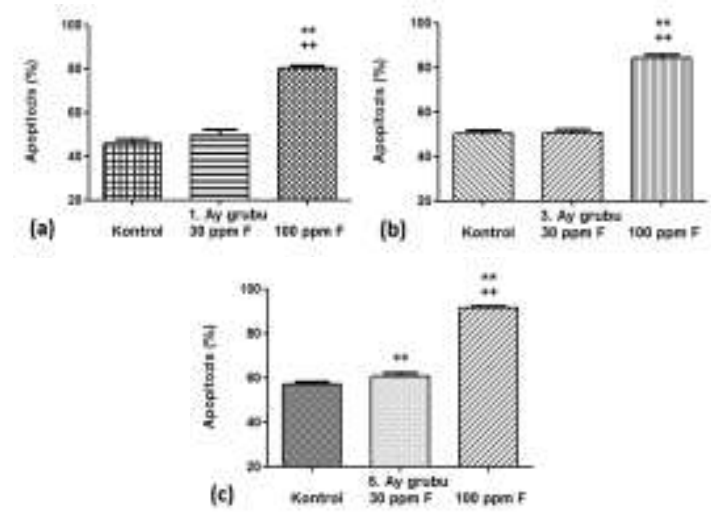

Şekil 1. Takip sürelerine göre (a) 1 , (b) 3 ve (c) 5 aylık sıçanların tubulus bölgesine ait apoptotik hücre değerleri

100 ppm F grubu 3. ay değerleri, Kontrol grubu 3. ay değerlerine göre $(p<0.0001)$ ve $30 \mathrm{ppm} F$ grupları 3. ay değerlerine göre $(p<0.0001)$ anlamlı şekilde yüksektir. Kontrol grubu ile 30 ppm F grubu 3. Ay değerleri arasında anlamlı bir fark görülmemiştir. (Şekil 1b)

100 ppm F grubu 5. ay değerleri, kontrol grubu 5. ay değerleri $(p<0.0001)$ ve $30 \mathrm{ppm} F$ grubu 5 . ay değerlerine göre $(p<0.0001)$ anlamlı şekilde yüksektir. Kontrol grubu ile 30 ppm F grubu 5. ay değerleri arasında anlamlı bir farklılık bulunmamaktadır. (Şekil 1c)

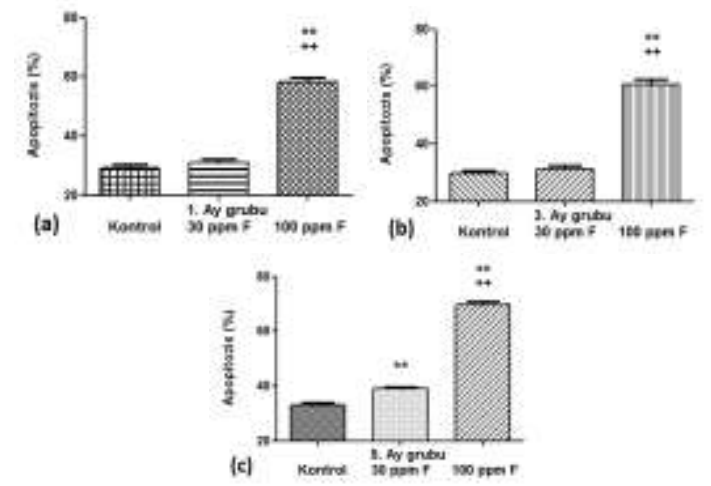

Şekil 2. Takip sürelerine göre (a) 1, (b) 3 ve (c) 5 aylık sıçanların glomerulus bölgesine ait apoptotik hücre değerleri ait apoptotik hücre değerleri

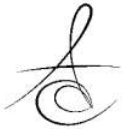




\section{Glomerulus bölgelerinde apoptotik hücrelerin analizi ve değerlendirilmesi}

Resim 2a' da 30 ppm F 3. ay grubunda glomerulus bölgesinde; Resim 2b'de ise 100 ppm $F 3$. ay grubunda glomerulus bölgesinde TUNEL yöntemi ile boyanmış apoptotik hücreler görülmektedir. Glomerulus bölgesinde, kontrol grubu 5. ay değerleri, kontrol grubu 1. ay değerlerine göre $(p<0.05)$ anlamlı şekilde yüksektir. Kontrol grubu 5 . ay değerleri ile kontrol grubu 3. ay arasında ve kontrol grubu 1. ay değerleri ile kontrol grubu 3. ay değerleri arasında anlamlı bir farklılık bulunmamaktadır. 30 ppm F grubu 5. ay değerleri, 30 ppm $F 1$. ay değerlerine göre $(p<0.0001)$ ve 30 ppm $F 3$. ay değerlerine göre $(p<0$. 0001) anlamlı şekilde yüksektir. 30 ppm F grubu 1. ay değerleriyle 3. ay değerleri arasında anlamlı bir farklılık bulunmamaktadır. 100 ppm F grubu 5. ay değerleri, 100 ppm F 1. ay değerlerine göre $(p<0.0001)$ ve 100 ppm F 3. ay değerlerine göre $(p<0.0001)$ anlamlı şekilde yüksektir. 100 ppm F grubu 1. ay değerleri ile 3. ay değerleri arasında anlamlı bir farklılık bulunmamaktadır. (Tablo 2)

Tablo 2. Böbrek dokusu glomerulus bölgeleri apoptotik hücre yüzde değerleri

\begin{tabular}{|c|c|c|c|c|}
\hline $\begin{array}{l}\text { Takip } \\
\text { süresi }\end{array}$ & $\begin{array}{c}\text { Kontrol } \\
\text { Ort } \pm \text { SS } \\
\text { (Medyan) }\end{array}$ & $\begin{array}{c}30 \mathrm{ppm} \\
\text { Ort } \pm \text { SS } \\
\text { (Medyan) }\end{array}$ & $\begin{array}{c}100 \mathrm{ppm} \\
\text { Ort } \pm \text { SS } \\
\text { (Medyan) }\end{array}$ & $p$ \\
\hline 1 ay & $\begin{array}{c}29.19 \pm 3.00 \\
(29.66)\end{array}$ & $\begin{array}{c}31.12 \pm 3.09 \\
(30.73)\end{array}$ & $\begin{array}{c}58.30 \pm 3.40 \\
(58.15)\end{array}$ & $<0.0001$ \\
\hline 3 ay & $\begin{array}{c}29.80 \pm 2.34 \\
(30.26)\end{array}$ & $\begin{array}{c}31.37 \pm 3.20 \\
(30.27)\end{array}$ & $\begin{array}{c}60.58 \pm 4.80 \\
(59.65)\end{array}$ & $<0.0001$ \\
\hline 5 ay & $\begin{array}{c}33.09 \pm 2.94 \\
(33.22)\end{array}$ & $\begin{array}{c}39.11 \pm 1.58 \\
(39.20)\end{array}$ & $\begin{array}{c}69.60 \pm 2.48 \\
(69.60)\end{array}$ & $<0.0001$ \\
\hline$p$ & 0.02 & $<0.0001$ & 0.001 & - \\
\hline
\end{tabular}

Glomerulus bölgesinde, 100 ppm F grubu 1. ay değerleri, kontrol grubu 1 . ay değerlerine göre $(p<0.0001)$ ve 30 ppm $F$ grupları 1. ay değerlerine göre anlamlı şekilde yüksektir. Kontrol grubu ile 30 ppm F grubu 1. ay değerleri arasında anlamlı bir farklılık bulunmamaktadır. (Şekil 2a)

Kontrol grubu ile, 30 ppm $F$ ve 100 ppm F gruplarının 3. ay apoptotik hücre değerleri şekil $2 b^{\prime}$ de gösterilmiştir. 100 ppm F grubu 3. ay değerleri, kontrol grubu 3. ay değerleri $(p<0.0001)$ ve 30 ppm $F$ grubu 3. ay değerlerine göre $(p<0.0001)$ anlamlı şekilde yüksektir. Kontrol grubu ile 30 ppm F grubu 3. ay değerleri arasında anlamlı bir farklılık bulunmamaktadır. ( $p>0.05)$ (Şekil 2b)

5. aydaki Kontrol, $30 \mathrm{ppm} F$ ve $100 \mathrm{ppm} \mathrm{F}$ gruplarının apoptotik hücre değerleri şekil $2 c^{\prime}$ de gösterilmiştir. 100 ppm F grubu 5. ay değerleri, Kontrol grubu 5. ay değerlerine göre $(p<0.0001)$ ve 30 ppm F grupları 5. ay değerlerine göre $(p<0.0001)$ anlamlı şekilde yüksektir. 30 ppm $F$ grupları 5. ay değerleri, Kontrol grubu 5 . ay değerlerine göre $(p<0.0001)$ anlamlı şekilde yüksektir. (Şekil 2c)

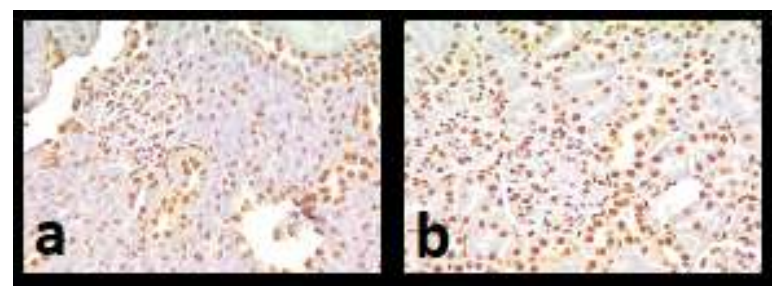

Resim 2. (a) $30 \mathrm{ppm} F$ 3. ay grubu ve (b) $100 \mathrm{ppm} F$ 3. ay grubu glomerulus bölgesinde TUNEL yöntemi ile boyanmış apoptotik hücreler $x 400$ büyütme

\section{TARTIŞMA}

Sistemik $F$ alımına bağlı böbreklerde büyük miktarlarda $\mathrm{F}$ birikiminin böbrek fonksiyonları üzerinde büyük etkileri vardır. ${ }^{23} \mathrm{Bu}$ çalışma, prenatal ve postnatal dönemde sistemik $F$ alımının sıçanların böbrek dokularındaki etkilerini değerlendirmektedir. Önceki çalışmalar genellikle $F$ toksisitesinin hayvanlarda postnatal etkileri üzerine yapılmıştır.

Anarudha ve ark. ${ }^{24}$ aşırı $\mathrm{F}$ alımının karaciğer ve böbrek dokularında meydana getirdiği yapısal değişiklikleri inceledikleri çalışmada $\mathrm{F}^{\prime}$ nin böbrek dokularında, glomeruluslarda atrofiye, tubul epitel hücrelerinde dejenerasyonlara ve glomeruluslarda hemorajik kanama odaklarına neden olduğunu gözlemlemişlerdir. Khadar Basha ve Jayantha Rao ${ }^{25}$ içme sularına, yüksek doz $F$ uygulanan farelerin böbrek dokularında, dilate olmuş tübüller, glomerulus bölgelerinde nekroz alanları, Bowman kapsüllerinde dejeneratif değişiklikler gözlemlemiştir. İçme sularına daha fazla oranda $F$ uygulanan farelerde ise glomerulus bölgelerinde ve Bowman kapsüllerinde büyük nekroz alanları ve tübül lümenlerinde genişlemeler görülmüştür. Bu çalışmada sıçanların kontrol grubuna kıyasla 1 . ay takiplerinde sadece anne sütü aldığında bile sıçan böbrek dokularında glomerulus ve tubulus bölgelerinde çok belirgin olmamakla beraber glomeruluslarda hafif derecede atrofi; tübül yapılarında ise yine hafif derecede dilatasyonlar (prenatal etki) gözlemlenmiştir. 3. ay gruplarında ise 30 ppm F grubunda hafif düzeyde

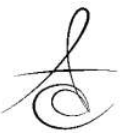


glomerül içinde kanama ve vasküler konjesyon izlenirken genel glomerül yapısında atrofi ve nekroz alanları (postnatal etki) gözlemlenmiştir. Tubuluslarda ise tübüler dilatasyon mevcuttur. 100 ppm F 3. ay grubunda böbrek dokularının glomerüller bölgelerinde büzülme ve küçülme şeklinde atrofi, tubulus bölgelerinde dilatasyon izlenmiştir. 5. aya ait grupla da kontrole göre 100 ppm F 5. ay grubu deney hayvanlarında histolojik açıdan glomerüllerde belirgin düzeyde atrofi ve nekroz alanları görülmüştür. Tubuluslarda ise dilatasyon mevcuttur. Bu deney grubu sıçanlarda böbrek dokularında hemorajik kanama odakları ve eritrositler de gözlemlenmiştir. Tespit ettiğimiz morfolojideki bu değişiklikler önceki birçok çalışmada açıklanan sonuçlara benzerlik göstermektedir. ${ }^{24-28}$

Apoptozis böbrek hasarının önemli bir nedenidir. ${ }^{29} \mathrm{Bu}$ nedenle, çalışmamız aşırı miktarda $\mathrm{F}$ alımında böbrek tübül ve glomerulus bölgelerinde morfolojik hücre hasarlarının ve apoptozise bağlı hücre yıkımlarının meydana geldiğini immünohistokimyasal yöntem ile açıkça gösteren özgün bir araştırmadır.

Murao ve ark. ${ }^{30}$ kronik fluoroziste böbrek dokularında meydana gelen hasarın oksidatif stres ve apoptozis ile böbrek tübüllerinin ve tübül hücrelerinin de etkilenebileceği belirtilmiştir. Chlubek ve ark. ${ }^{31}$, Kubota ve ark. $^{32}$, Li ve ark. ${ }^{33}$ kronik fluorozisin yumuşak dokularda oksidatif strese neden olduğunu ve bunun sonucunda canlı doku hücrelerinde apoptozisin meydana gelebileceğini belirtmişlerdir. $\mathrm{Yu}$ ve ark. $^{34}$ sıçanlara içme sularına $50 \mathrm{mg} / \mathrm{l} \mathrm{NaF}$ ve selenyum ile bakır elementlerini 6 ay uygulayarak takip etmişler ve sıçan böbrek hücrelerinde $\mathrm{NaF}^{\prime}$ in böbrek hücrelerinde apoptozisi arttırdığı, selenyum ve bakırın ise azalttığı tespit etmiştir. Zhan ve ark. ${ }^{35}$ domuzlarda yaptıkları çalışmalarında diyetlerine 0 (kontrol), 100 ve 250 mg/kg F 50 gün boyunca uygulandıktan sonra $F$ artışına bağlı böbrek dokularında apoptotik hücrelerin arttırdığını, böbrek yapı ve fonksiyonlarında hasarlara neden olduğunu belirtmişlerdir.

Araştırmamızda, kronik fluorozis sonucu böbrek dokularında tubulus ve glomerulus bölgelerinde meydana gelen apoptozisin değerlendirilmesinde, takip sürelerine göre bütün deney gruplarında 5 . ay gruplarının apoptotik hücre sayılarının anlamlı bir şekilde arttığını gözlemledik. Deney gruplarının 1. ay ve 3. ay grupları arasında ise anlamlı bir farklılık değerlendiremedik. Kontrol gruplarında ilerleyen yaş ile beraber apoptozisin görülmesi zaten beklenen bir bulgu olduğunu göstermekte ancak bu durumun $\mathrm{F}$ gruplarında arttığı görülmüştür. Çalışmamızda, F varlığında, böbrek dokularının tubulus ve glomerulus bölgelerinde meydana gelen apoptotik hücre sayılarının, Murao ve ark. ${ }^{30}$, Yu ve ark. ${ }^{34}$, Zhan ve ark. ${ }^{35}$, Karube ve ark. ${ }^{36}$, Flora ve ark. ${ }^{37}$, Mohammadi ve ark. ${ }^{38}$ ve Song ve ark. ${ }^{39}$ elde ettikleri bulgulara uyumlu olarak, 100 ppm F gruplarında, kontrol ve 30 ppm F gruplarına kıyasla anlamlı bir şekilde arttığını tespit ettik.

Her ne kadar sıçan metabolizması ile insan metabolizması arasında önemli farklılıklar bulunsa da bu etkilerin insanda da oluşabileceği endişesi her zaman bulunmaktadır. İnsanda yaklaşık $10 \mathrm{ppm}$ ve üstü sistemik $F$ alınmasına eşit olan bu çalışmada benzer patolojik etkilerin yumuşak dokularda da oluşabileceği öngörülebilir. Fakat bu miktarın aşırı doz olduğu unutulmamalıdır. İnsanda bu doza ancak endemik bölgelerde ulaşmak söz konusu olabilir.

\section{SONUÇ}

Hayvan çalışmalarında toksisite riskini görebilmek için normalden yüksek değerler kullanılmaktadır. $\mathrm{Bu}$ çalışmada olası toksik etkilerin gözlenebilmesi için yüksek $F$ dozları kullanılmıştır. F uygulamaları, çocuk diş hekimliğinde temel koruyucu yöntemlerin başında gelmektedir. Bu amaçla geliştirilen ürünlerin koruyucu hekimliğe katkısı yatsınamaz. Bu ürünler çocuk diş hekimliğinin en temel ve sık kullanılan ajanlarıdır. Ancak bu ürünlerin piyasada bol miktarda bulunması, kolay ulaşılabilir olması ve bilinçsiz kullanımı yanında tahmin edilemeyen birçok çevresel faktörün de eklenmesiyle beraber çocuklarda önemli risklerin meydana gelebileceğini gözardı edilmemelidir. Buna böbrek nakli, vezikoüreteral reflü, konjenital kistik böbrek hastalıkları ve endokrin hastalıklar gibi risk grupları da dahil edilebilir. Kontrolsüz F uygulamalarını önlemek ve toplumu bu konuda da bilinçlendirmek gerekmektedir. Ayrıca, $\mathrm{F}$ toksisitesi ile ilgili daha kapsamlı ve kontrollü çalışmalara da hala intiyaç vardır. Özetle, bu makaledeki çalışmaların sonuçları, erken gelişim aşamaları sırasında yüksek $F$ alımının histopatolojik değişiklikler ve artmış apoptozis dahil olmak üzere böbrek hücreleri üzerinde belirgin negatif etkiler uyguladığını göstermektedir.

NOT: Calışmada herhangi bir yazar, kurum ya da kuruluş ile çıkar çatışması içerisinde bulunmamaktadır. Makale daha önce hiçbir yerde yayınlanmamış ve yayınlanmak üzere işlem görmemektedir 


\section{KAYNAKLAR}

1. Whitford GM. The physiological and toxicological characteristics of fluoride. J Dent Res 1990; 69:539-44.

2. Fejerskov O, Ekstrand J. Burt BA. Fluoride in dentistry. 2nd. ed. Munksgraad, Copenhagen; Boisen Print: 1996.

3. Fawell J, Bailey K, Chilton J, Dahi E, Fewtrell L, Magara Y. Fluoride in drinking water. London; IWA Publishing: 2006. p.346-352.

4. Agalakova IN, Gusev GP. Molecular mechanisms of cytotoxicity and apoptosis Induced by Inorganic fluoride. ISRN Cell Biology 2012:1-16.

5. Doull J, Boekelheide K, Farishian BG, Isaacson RL, Klotz JB, Kumar JV. Fluoride in drinking water: A scientific review of EPA's standards. Washington, DC. Fluoride 2006; 80:74-80.

6. WHO (World Health Organization). Guidelines for drinking water quality. 3th ed, Geneva;2008. p.221-459.

7. Whitford GM. Effects of plasma fluoride and dietary calcium concentrations on GI absorption and secretion of fluoride in the rat. Calcif Tissue Int 1994; 54: 421-5.

8. Den Besten PK. Dental fluorosis: its use as a biomarker. Adv Dent Res 1994; 8:105-10.

9. Michel-Crosato E, Biazevic MG, Crosato E. Relationship between dental fluorosis and quality of life: a population based study. Braz Oral Res 2005; 19:150-55.

10. Aoba T, Fejerskov O. Dental fluorosis: chemistry and biology. Crit Rev Oral Biol Med 2002; 13:15570.

11. Pendrys DG. Risk of enamel fluorosis in nonfluoridated and optimally fluoridated populations: considerations for the dental professional. J Am Dent Assoc 2000; 13:746-55.

12. Bartlett JD, Dwyer SE, Beniash E, Skobe Z, PayneFerreira TL. Fluorosis: a new model and new insights. J Dent Res 2005; 84:832-6.

13. Lantz O, Jouvin MH, DeVernejoul MC, Druet P. Fluoride-induced chronic renal failure. Am J Kidney Dis 1987; 10:136-9.

14. Villa A, Anabalon M, Zohouri V, Maguire A, Franco AM, Rugg-Gunn A. Relationships between fluoride intake, urinary fluoride excretion and fluoride retention in children and adults: an analysis of available data. Caries Res 2010; 44:60-8.
15. Reggabi M. Renal functions in residents of endemic fluorosis in southern Algeria. Fluoride 1984; 17:3541.

16. Wimalawansa, Sunil J. Molecular and cellular toxicity of fluoride in mystery, tubulointerstitial chronic kidney disease: A systematic review. Rev Environmental Sci Bio/Technology 2020; 19:11747.

17. Wang, H. W., Zhu, S. Q., Liu, J., Miao, C. Y., Zhang, Y., \& Zhou, B. H. Fluoride-induced renal dysfunction via respiratory chain complex abnormal expression and fusion elevation in mice. Chemosphere 2020; 238:124607.

18. Singh PP, Barjatiya MK, Dhing S, Bhatnagar R, Kothari S, Dhar V. Evidence suggesting that high Intake of fluoride provokes nephrolithiasis in tribal populations. Urol Res 2001; 29:238-44.

19. Ameisen JS. The origin of programmed cell death. Sci 1996; 272:1278-79.

20. Bellamy CO, Malcomson RD, Harrison DJ, Wyllie $\mathrm{AH}$. Cell death in health and disease: the biology and regulation of apoptosis. Cancer Biol 1995; 6:316.

21. Cummings MC, Winterford CM, Walker NI. Apoptosis. Am J Surg Pathol 1997; 21:88-101.

22. Güner Ş, Bozkurt S, Haznedaroğlu E, Mentes A. Dental fluorosis and catalase Immunoreactivity of the brain tissues in rats exposed to high fluoride pre and postnatally. Biol Trace Element Res 2016; 174:150-7.

23. Li XL. The research progress of oxidative stress on non phrenology damage in fluorosis. Med Inform 2010; 23:347-48.

24. Anarudha CD, Kanno S, Hirano S. Fluoride induces apoptosis by caspase- 3 activation in human leukemia HL-60 cells. Arch Toxicol 2000; 74:22630.

25. Khadar Basha S. ve K. Jayantha Rao. Sodium fluoride induced histopathological changes in liver and kidney of albino mice. Acta Chim Pharm Indica 2014; 4:58-62.

26. Shashi A, Singh JP, Thapar SP. Toxic effects of fluoride on rabbit kidney. Fluoride 2002; 35:13850.

27. Karaöz E, Gülle, Mumcu EF, Gökçimen A, Öncü M. The structural changes in second generation at the rats kidney and liver tissues which have experimentally acquired chronic fluorosis. Turk Klin Med Sci 2003; 23:129-34. 
28. Kobayashi CAN, Leite AL, Silva $T L$, Santos LD, Nogueira FCS, Oliveira RC, Palma MS, Domont GB, Buzalaf MAR. Proteomic analysis of kidney in rats chronically exposed to fluoride. Chemico-Biological Interactions 2009; 180:305-11.

29. Quadri JA, Sarwar S, Sinha A, Kalaivani M, Dinda AK, Bagga A, Shariff A. Fluoride-associated ultrastructural changes and apoptosis in human renal tubule: a pilot study. Human \& experimental toxicology 2018; 37:1199-1206.

30. Murao H, Sakagami N, Iguchi T, Murakami T, Suketa $Y$. Sodium fluoride increase intracellular calcium in rat renal epithelial cell line NRK-52E. Biol Pharm Bull 2000; 23:581-84.

31. Chlubek D, Grucka-Mamczar E, Birkner E, Polaniak $\mathrm{R}$, Stawiarska-Pieta B, H Duliban H. Activity of pancreatic antioxidative enzymes and malondialdehyde concentrations in rats with hyperglycemia caused by fluoride intoxication. J Trace Elem Med Biol 2003; 17:57-60.

32. Kubota K, Lee DH, Tsuchiya M, Young CS, Everett ET, Martinez-Mier EA, Snead ML, Nguyen L, Urano F, Bartlett JD. Fluoride induces endoplasmic reticulum stress in ameloblasts responsible for dental enamel formation. J Biol Chem 2005; 280:23194-202.

33. Li XL. The research progress of oxidative stress on non phrenology damage in fluorosis. Med Inform 2010; 23:347-48.

34. Yu RA, Xia T, Wang AG, Chen XG. Effects of selenium and zinc on renal oxidative stress and apoptosis induced by fluoride in rats. Biomed Environment Sci 2006;19: 439-44.

35. Zhan X, Wang M, Xu ZR, Hangzhou JL. Toxic effects of fluoride on kidney function and histological structure in young pigs. Res Report Fluorid 2000; 39:22-6.

36. Karube H., G. Nishitai, K. Inageda, H. Kurosu, M. Matsuoka. NaF activates MAPKs and induces apoptosis in odontoblast-like cells, J Dent Res. 2009; 88:461-65.

37. Flora SJ, Mittal M, Mishra D. Co-exposure to arsenic and fluoride on oxidative stress, glutathione linked enzymes, biogenic amines and DNA damage in mouse brain. J Neurol Sci 2009; 285:198-205.

38. Mohammadi S, Movahedin M, Mowla SJ. Upregulation of CatSper genes family by selenium. Reprod Biol Endocrinol 2009; 81:539-44.
39. Song Y, Wang J, Xu H, Du Z, Zhang G, Selim HA, Li G, Wang Q, Gao Z. Fluorosis caused cellular apoptosis and oxidative stress of rat kidneys. Chemical Res Chinese Univ 2013; 29:263-9.

\author{
Sorumlu Yazarın Yazışma Adresi \\ Dr. Öğr. Üyesi Serhat KARACA \\ Erzincan Binali Yıldırım Üniveristesi \\ Ağız ve Diş Sağlığı Hastanesi Fatih, \\ Terzibaba Cd. No:4, 24180 \\ Erzincan Merkez/Erzincan \\ e-mail: dtserhatkaraca@hotmail.com
}

